\title{
Variations in anterior fontanel sizes in nigerian children in port harcourt metropolis
}

\begin{abstract}
Background: At birth, the human baby has six fontanels - the anterior, posterior, two mastoids and two sphenoid fontanels. The diamond shaped anterior fontanel (AF) is the largest and most significant for clinical purposes. Useful information can be obtained from examining an infant's anterior fontanel as it offers the clinician a window into an infant's developing brain and general state of health. Due to the wide variations in the size of the AF in health and disease, it is necessary to have local reference values for any given population. This will aid early diagnosis of certain conditions associated with abnormal fontanels.

Results: Two thousand eight hundred and ninety-five infants comprising 313 newborns and 321 from each of the other age categories were studied. There were 1391males and 1504 females giving a M: F ratio of $1: 1.1$. AF sizes decreased significantly with increasing post natal age in both sexes $\mathrm{p}<0.001$. There was also a significant relationship between AF size and social class and a wide variation in $\mathrm{AF}$ sizes among various ethnic groups $(p<0.001)$ with the Ogonis having largest fontanels in newborns $(6.4 \pm 1.5 \mathrm{~cm})$ and the Hausa/Fulani having the least $(3.0 \pm 3.5 \mathrm{~cm})$.
\end{abstract}

Conclusion: AF sizes decreased with increasing post natal age. Social class and ethnic origin significantly affected AF sizes. There is need for different populations to have their own reference values
Volume 8 Issue I - 2018

\section{Okorie EMC, Opara PI, Alikor EAD,Akani NA \\ Department of Paediatrics, University of Port Harcourt} University of Port Harcourt Teaching Hospital, Nigeria

Correspondence: Opara Peace lbo, Department of Paediatrics, University of Port Harcourt/ University of Port Harcourt Teaching Hospital. Port Harcourt, Rivers State, Nigeria, Tel 8037078844,Email peaceibo@yahoo.com.au

Received: November 10, 2017 | Published: January II, 2018

Keywords: variations, anterior fontanel, Nigerian, children

\section{Introduction}

Examination of the anterior fontanel (AF) is an essential part of the neuro-developmental evaluation of newborns and offers the physician the possibility of determining changes in intracranial pressure and abnormalities of skeletal development in infancy. ${ }^{1-3}$ The word 'fontanel' originated from the Latin word 'fonticulus' and the old French Word 'fontaine' meaning little fountain or spring..$^{4-6}$ Fontanels are the fibrous membrane-covered gaps created where more than two cranial bones are juxtaposed as opposed to sutures which are narrow seams of fibrous connective tissues that separate any two flat bones of the skull..$^{1,6,7}$

Variation in size is a key feature of the normal anterior fontanel..$^{1,3,8}$ The size of the AF is influenced by factors such as gestational age, post-natal age, gender as well as racial and environmental factors. ${ }^{8-12}$ Faix, ${ }^{12}$ in 1982 reported larger AF size in black neonates compared to their white counterparts while some researchers, ${ }^{3,9,10,12}$ have documented increasing AF sizes with advancing gestational age. In contrast to the findings by other researchers, ${ }^{9,10,12,13}$ Mir and Wieslaw ${ }^{11}$ reported a significant gender difference in the size of the AF. Kiesler and Ricer ${ }^{3}$ have put the average time of closure of the AF at 13.8 months. In the study by Omotade et al., ${ }^{14}$ at Ibadan Nigeria, 53\% of the subjects had a closed AF at 12 months of age.

There is a dearth of data on the size of the anterior fontanel in Nigeria and Africa in general compared to Western nations. The range of normal values of various anthropometric parameters including anterior fontanel sizes have been established for Caucasian and Asian populations. ${ }^{15-17}$ In view of the established racial differences in anthropometric parameters, which are genetically determined, Caucasian figures may not be universally applicable. Hence there is need to obtain local values from well-defined populations as a reference in the evaluation of the child with dysmorphic features in order to avoid errors of classification due to differences arising from variations in the normal range. Since the size of the AF also varies widely in various disease conditions, the range of normal sizes of the AF derived from a given community which can then be regarded as reference values for that population is therefore essential for early detection of such diseases in order to ensure early treatment and a better outcome. The aim of this study therefore was to determine the variations in the sizes of the anterior fontanel (AF) from 48 hours to 24 months of age in apparently healthy Nigerian children in Port Harcourt.

\section{Subjects and methods}

The study was a cross sectional and analytical study carried out to determine the variations in the size of anterior fontanels from birth to 24 months of age in apparently healthy Nigerian children in Port Harcourt. It was carried out at the Post-Natal Wards and Special Care Baby Unit (SCBU) of the University of Port Harcourt Teaching Hospital, (UPTH); and the Well Infants Clinics of UPTH and the Braithwaite Memorial Specialist Hospital (BMSH), Port Harcourt, Nigeria. The UPTH is a federal tertiary health institution serving the Rivers State and the neighbouring states of Bayelsa, Abia, Imo, and AkwaIbom. It provides specialised health care in all specialties including Paediatrics and Obstetrics and Gynaecology. The average number of newborns in the post-natal ward is 1700 per year. The Special Care Baby Unit (SCBU) of the Paediatrics Department is located adjacent to the Labour Ward and has a maximum capacity for 30 in-patients. Routine newborn examination is carried out on all babies delivered in the hospital and includes measurement of anthropometric parameters and system examination. Newborns who require specialised care are admitted into the SCBU for further management. Babies who have no indications for admission or observation in the SCBU are transferred to the Post-Natal Ward where they are allowed a further observation time of 48 hours. Well babies are routinely discharged after 48 hours to the Post-Natal Clinic where they are further reviewed along with 
their mothers at 6 weeks of age, and if well, they are sent to the Well Infant Clinic for immunization and further health education of the mothers. Braithwaite Memorial Specialist Hospital (BMSH) is the apex state owned tertiary health centre and acts as a referral centre for the primary health centres especially in the area of maternal and child health including childhood immunizations.

Port Harcourt City is cosmopolitan and host to major indigenous and multinational companies in the oil and gas, manufacturing, banking, telecommunications construction and health sectors, employing staff from diverse ethnic nationalities.

All newborns of Nigerian descent admitted at the Post-Natal Wards and the SCBU and all Nigerian children aged 6 weeks to 2 years attending the Well Infant Clinics of tertiary institutions in Port Harcourt metropolis, who met the inclusion criteria constituted the study population.

Included were neonates delivered at 28 to 42 weeks' gestational age with post natal ages of 48 hours to 7 days, neurologically stable non critically ill babies in the SCBU, and Nigerian children 6 weeks to 24 months old. Excluded were critically ill babies, neonates less than 48 hours or more than 7 days old, babies born to non Nigerian parents, those with caput succedaneum and cephalhaematomas, those with stigmata of chromosomal anomalies or hypothyroidism and refusal by the parents to give consent.

Three hundred and thirteen newborns and 321 infants in each of the age categories 6, 10 and 14 weeks; 6, 9, 12, 18 and 24 months of age respectively were recruited from the Post-Natal Ward and the SCBU. The choice of the defined ages was made because the ages corresponded to the Nigerian National Programme on Immunization schedule and facilitated the recruitment of subjects.

For the purpose of this study, the size of the anterior fontanel was taken as the mean of the antero-posterior and transverse diameters measured along the sagital and coronal sutures respectively. Using a modified version of Faix's ${ }^{12}$ method, each subject was held upright in a sitting position by the mother/care-giver with the head supported and held firmly by the Research Assistant while the Measurer introduced the tip of the index and the middle fingers of his/her left hand into the two corners of the lateral dimensions of the anterior fontanel. With a pair of dividers held in the right hand, the inner margins of the distal end of the pair of dividers were applied firmly against the outer border of the two fingers of the left hand at the corners of the fontanel. The pair of dividers was then placed on a tape measure firmly positioned on a table and the distance between the inner borders of the pair of dividers was read-off on the tape. The process was repeated with the index and middle fingers placed at the corners of the antero-posterior dimension of the AF. The size of the anterior fontanel in centimetres was derived from the relationship: (length of $\mathrm{AF}+$ width of $\mathrm{AF}$ )/2, the length and width representing the antero-posterior and the laterolateral diameters respectively. Any fontanel too small to be measured was adjudged closed.

Data were collected on a Proforma for each of the different age groups and information obtained included demographic information of the child and mother, as well as other relevant obstetric data. These were numbered serially until the minimum sample size for each age category was reached. Measurements were also filled in as they were being obtained.

Ethical clearance and a written permission were obtained from the Ethics Committee of the University of Port Harcourt Teaching Hospital, and the Braithwaite Memorial Specialist Hospital respectively. Written informed consent was also obtained from the parent(s) or care-giver(s) of each child before recruitment into the study.

Subjects were stratified into different socio-economic classes based on the socio-economic classification described by Oyedeji. ${ }^{19}$

Data were analysed using the Statistical Package for Social Sciences (SPSS) Version 15.0. ${ }^{20}$ The mean, standard deviation and range of each continuous variable and other derived indices including the 5th, 10th, 25th, 75th, and 95th percentiles were computed and presented as graphs, and tables in simple proportions. The differences in means were compared using Student's $t$ test while Chi-square test was used to compare proportions and rates. Multiple comparisons of the differences in mean AF between age groups was carried out using Dunnettes Test. ${ }^{20}$ Statistical significance at 95\% confidence interval was set at $p$ - value $<0.05$.

\section{Results}

Two thousand eight hundred and ninety-nine $(2,899)$ subjects were recruited into the study. One newborn and three infants were excluded on the basis of incomplete data due to mother's uncertainty of the child's age leaving a total study population of 2,895 . Of these, $1391(47.5 \%)$ were males and $1504(52.5 \%)$ females, giving a male to female ratio of 1:1.1. There was no statistically significant difference between the proportion of males and females. The age and sex distribution is as shown in Table 1.

Table 2 shows the distribution of the newborns by gender and gestational age. Of the 313 newborns, $250(79.9 \%)$ were term while the $63(20.1 \%)$ were preterm. The proportion of males to females among the term and preterm newborns was $0.96: 1$ and $0.7: 1$ respectively. Of the two hundred and fifty term infants, $146(58.4 \%)$ were delivered at 37-39 weeks of gestation and 104 (41.6\%) were born at 40-42 weeks gestation. Among the 63 preterm newborns, 47 $(74.6 \%)$ and $16(25.4 \%)$ were delivered at 33 - 36 weeks and $28-32$ weeks of gestation respectively.

Table 3 shows the distribution of the study subjects by ethnic group. The Igbo was the largest ethnic group followed by the Ikwere/ Etche group and the Hausa/Fulani the least.

Table I Distribution of the 2895 subjects by age and gender

\begin{tabular}{|c|c|c|c|}
\hline \multirow{2}{*}{ Age } & Male & Female & Total \\
\hline & No (\%) & No (\%) & No (\%) \\
\hline 2-7 days & I53 (I I.0) & $160(10.6)$ & $313(10.8)$ \\
\hline 6 wks. & 165 (II.9) & $158(10.5)$ & 323 (II.2) \\
\hline 10 wks. & $167(12.0)$ & $158(10.5)$ & 325 (II.2) \\
\hline 14 wks. & I54 (II.I) & $168(11.2)$ & $322(11.1)$ \\
\hline $6 \mathrm{mo}$. & I 58 (I I.4) & I67 (II.I) & $325(11.2)$ \\
\hline 9 mo. & I56 (II.2) & 165 (II.0) & $321(11.1)$ \\
\hline 12 mo. & I64 (II.8) & $157(10.4)$ & $321(11.1)$ \\
\hline $18 \mathrm{mo.}$ & $140(10.1)$ & $18 \mid(\mid 2.1)$ & $32 I(I I . I)$ \\
\hline 24 mo. & $133(9.6)$ & 191 (12.7) & 324 (II.2) \\
\hline Total & |39| (100.0) & $1504(100.0)$ & $2895(100)$ \\
\hline
\end{tabular}

$X^{2}=12.34, d f=8, p$-value $=0.1366$

Table 2 Distribution of newborns by gestational age and gender

\begin{tabular}{llll}
\hline Gestational Age & Male (\%) & Female (\%) & Total (\%) \\
\hline Preterm & $26(17.0)$ & $37(23.1)$ & $63(20.1)$ \\
Term & $127(83.0)$ & $123(76.9)$ & $250(79.9)$ \\
Total & $153(100.0)$ & $160(100.0)$ & $313(100)$ \\
\hline
\end{tabular}

$X^{2}=I .829, d f=I, p=0.176$ 
Table 3 Distribution of the subjects by ethnic groups

\begin{tabular}{lll}
\hline Ethnic Group & No & Percentage \\
\hline Igbo & 1040 & 35.9 \\
Ikwerre/Etche & 505 & 17,4 \\
Yoruba & 217 & 7.5 \\
Urhobo/Itsekiri & 215 & 7.4 \\
ljaw/Kalabari/Okirika & 195 & 6.7 \\
Anang/lbibio/Oron & 180 & 6.2 \\
Ogoni & 119 & 4.1 \\
Bini/Esan & 112 & 3.9 \\
Hausa/Fulani/Tiv/Langtan, & 31 & 1.1 \\
Others* & 284 & 9.8 \\
Total & 2895 & 100.0
\end{tabular}

*Efik, Ekpeye, Ibani, Idoma, Ndoni and others

Table 4 shows the distribution of the study subjects according to the various social classes.

Table 4 Distribution of subjects by social class

\begin{tabular}{ll}
\hline Social Class & No (\%) \\
\hline Class I & $686(23.7 \%)$ \\
Class II & $1079(37.3 \%)$ \\
Class III & $861(29.7 \%)$ \\
Class IV & $227(7.8 \%)$ \\
Class V & $42(1.5 \%)$ \\
Total & $2895(100 \%)$ \\
\hline
\end{tabular}

$1,765(61 \%)$ were of the higher social classes (I and II), whereas $269(9.3 \%)$ of the subjects were of the lower social classes.

Table 5 shows the mean AF size of term and preterm newborns. There were no significant differences between males and females or between term and preterm newborns, $p>0.05$.

Table 6 shows the distribution of mean anterior fontanel size by age and sex. There was a highly statistically significant trend of decreasing AF size with age in both males and females with the $p$ - values $<0.001$ for ANOVA.There was no significant difference in mean AF size between males and females except at 10 weeks (0.029), 6 months (0.04) 12 months (0.008) and 24 months (0.002).

The results of multiple comparisons of differences in mean AF between the different age groups is shown in table 7. There was a statistically significant difference between the mean AF size of newborns and those of infants aged 6 months, 12, months 18 months and 24 months $(p<0.001)$. There was also a statistically significant difference between the mean AF size at 6 months and at 12, 18 and 24 months, and between those 12 and 18 months. There was no significant difference between the mean AF size at 18 months and 24 months.

Mean difference and 95\% confidence interval are given in $\mathrm{cm}$

*Highly Statically significant mean differences.

Figure 1 is a scatter plot illustrating the variations in AF sizes with increasing post-natal age. There was a strong negative correlation between AF size and post-natal age in both males $(\mathrm{r}=-0.747 ; \mathrm{p}=$ $0.000)$ and females $(r=-0.782 ; p=0.000)$. The mean AF size in males was significantly higher than that of the females, with more females having a closed anterior fontanel with advancing post-natal age beyond 9 months of age $(p<0.05)$.

The variation in percentile of anterior fontanel size with age is illustrated in Table 8. The 5th, 50th, and 95th percentiles of the AF size at birth were $1.3,4.7$ and $6.7 \mathrm{~cm}$. At 24 months, the values were $0.0,0.0$ and $1.4 \mathrm{~cm}$ respectively. The variations in mean AF size with increasing post-natal age was statistically significant (ANOVA = 537.37, $\mathrm{p}<0.001)$. This is illustrated in Figure 2.

Table 9 shows the relationship between AF size and social class. Among the newborns, the AF was largest in the subjects belonging to social class $\mathrm{V}$ and least in those of class II. The subjects belonging to social class I had the largest AF size at 2-7 days, 6 weeks, 10 weeks, 14 months of life while the AF was not patent in those belonging to class $\mathrm{V}$ at 9, 18 and 24 months of age. The difference in the mean AF sizes between the various social classes was highly statistically significant at all the age categories except at 2-7 days, 14 weeks, 6 months and 18 months. This is also illustrated in figure 3 .

The distribution of mean AF sizes by ethnic group among the newborns (Table 10). Those from the Ogoni ethnic group had the largest $(6.4 \pm 1.5 \mathrm{~cm}) \mathrm{AF}$ size while the Hausa/Fulani had the least $(3.0 \pm 3.5 \mathrm{~cm})$ AF size. There was a highly statistically significant difference in the mean AF size between the different ethnic groups $(p<0.001)$.

ANOVA $=3.590, \mathrm{p}<0.001$

$\mathrm{AF}$ size given in $\mathrm{cm}$

Table 11 shows the proportion of the subjects in each age group with a closed anterior fontanel. The number with closed AF was 76 $(23.68 \%)$ at 12 months, $273(85.1 \%)$ at 18 months and288 (88.9\%) at 24 months. Nine $(2.9 \%)$ of the 313 newborns had closed AF. The proportion of subjects with a closed AF at different age categories is illustrated in figure 4 .

Table 5 Distribution of mean anterior fontanel sizes of newborns by gestational age and gender

\begin{tabular}{|c|c|c|c|c|c|c|c|c|}
\hline \multirow{3}{*}{$\begin{array}{l}\text { Gestational Age } \\
\text { Preterm }\end{array}$} & \multicolumn{6}{|c|}{ Anterior fontanel sizes $(\mathrm{cm})$} & \multirow{3}{*}{ t-test } & \multirow{3}{*}{ p-value } \\
\hline & \multicolumn{2}{|c|}{ Male } & \multicolumn{2}{|c|}{ Female } & \multicolumn{2}{|c|}{ All Subjects } & & \\
\hline & No. & Mean $\pm(S D)$ & No. & Mean \pm (SD) & \multicolumn{2}{|c|}{ No Mean士(SD) } & & \\
\hline $28-32$ & 7 & $4.4(1.8)$ & 9 & $3.8(2.0)$ & 16 & $4.0(1.9)$ & 0.62 & 0.545 \\
\hline $33-36$ & 19 & $4.5(1.7)$ & 28 & $4.5(2.2)$ & 47 & $4.5(2.0)$ & 0.054 & 0.957 \\
\hline \multicolumn{9}{|l|}{ Term } \\
\hline $37-39$ & 68 & $4.6(1.7)$ & 78 & $4.6(1.8)$ & 146 & $4.6(1.8)$ & -0.073 & 0.942 \\
\hline $40-42$ & 59 & $4.4(1.4)$ & 45 & $4.5(1.4)$ & 104 & $4.4(1.4)$ & -0.31 & 0.757 \\
\hline All Subjects & 153 & $4.5(1.6)$ & 160 & $4.5(1.8)$ & 313 & $4.5(1.7)$ & 0.052 & 0.958 \\
\hline ANOVA & & 0.18 & & 0.56 & 0.61 & & & \\
\hline$p$-value & & 0.91 & & 0.642 & $0.60 \varepsilon$ & & & \\
\hline
\end{tabular}


Table 6 Mean AF sizes by postnatal age and gender

\begin{tabular}{|c|c|c|c|c|c|c|c|c|}
\hline \multirow{3}{*}{ Post natal age } & \multicolumn{6}{|c|}{ Anterior fontanel sizes $(\mathrm{cm})$} & \multirow{3}{*}{ t-test } & \multirow{3}{*}{$p$-value } \\
\hline & \multirow{2}{*}{\multicolumn{2}{|c|}{$\begin{array}{l}\text { Male } \\
\text { No. Mean } \pm(S D)\end{array}$}} & \multicolumn{2}{|c|}{ Female } & \multicolumn{2}{|c|}{ All Subjects } & & \\
\hline & & & No. & Mean $\pm($ SD) & \multirow{2}{*}{$\begin{array}{l}\text { No. } \\
313\end{array}$} & \multirow{2}{*}{$\begin{array}{r}\text { Mean } \pm(\text { SD) } \\
4.5(1.7)\end{array}$} & & \\
\hline $2-7$ days & 153 & $4.5(1.6)$ & 160 & $4.5(1.8)$ & & & 0.057 & 0.095 \\
\hline 6 wks & 165 & $4.3(1.5)$ & 158 & $4.2(1.3)$ & 323 & $4.3(1.4)$ & 1.179 & 0.239 \\
\hline 10 wks & 167 & $4.1(1.3)$ & 158 & $3.8(1.6)$ & 325 & $3.9(1.5)$ & 2.192 & 0.029 \\
\hline 14 wks & 154 & $3.6(1.2)$ & 168 & $3.5(1.2)$ & 322 & $3.6(2.2)$ & 0.43 & 0.667 \\
\hline $6 \mathrm{mo}$ & 158 & $3.3(1.2)$ & 167 & $2.9(1.4)$ & 325 & $3.1(1.3)$ & 2.21 & 0.028 \\
\hline $9 \mathrm{mo}$ & 156 & $2.3(1.3)$ & 165 & $2.6(1.3)$ & 321 & $2.5(1.2)$ & 1.45 & 0.148 \\
\hline $12 \mathrm{mo}$ & 164 & $2.0(1.6)$ & 157 & I.6 (I.0) & 321 & $1.8(1.3)$ & 2.672 & 0.008 \\
\hline $18 \mathrm{mo}$ & 140 & $0.3(0.7)$ & 181 & $0.1 \quad(0.4)$ & 321 & $0.2(0.6)$ & $\mathrm{I} .885$ & 0.06 \\
\hline $24 \mathrm{mo}$ & 134 & $0.4(1.0)$ & 190 & $0.1 \quad(0.4)$ & 324 & $0.2(0.7)$ & 3.075 & 0.002 \\
\hline All Subjects & 1391 & $2.9(2.2)$ & 1504 & $2.52 .0)$ & 2895 & $2.7(2.1)$ & 4.387 & 0 \\
\hline ANOVA & & 226.931 & & 16.07 & & 537.4 & & \\
\hline$p-$ value & & 0 & & 0 & & 0 & & \\
\hline
\end{tabular}

Table 7 Dunnett's multiple comparisons of differences in mean AF between different age groups

\begin{tabular}{|c|c|c|c|c|c|}
\hline \multirow{2}{*}{ (I) Age Category } & \multirow{2}{*}{ (J) Age Category } & \multirow{2}{*}{ Mean Difference (I-J) } & \multicolumn{2}{|c|}{ 95\% Confidence Interval } & \multirow{2}{*}{$p$-value } \\
\hline & & & Lower limit & Upper limit & \\
\hline \multirow{4}{*}{2 - 7 days } & 6 months & $1.3835^{*}$ & 1.056 & $1.71 \mathrm{I}$ & $<0.001$ \\
\hline & 12 months & $2.7237^{*}$ & 2.393 & 3.055 & $<0.001$ \\
\hline & 18 months & $4.3009 *$ & 4.027 & 4.575 & $<0.001$ \\
\hline & 24 months & $4.276 I *$ & 3.994 & 4.559 & $<0.001$ \\
\hline \multirow{3}{*}{6 months } & 12 months & $\mathrm{I} .340 \mathrm{I} *$ & 1.056 & 1.625 & $<0.001$ \\
\hline & 18 months & $2.9174 *$ & 2.702 & 3.133 & $<0.001$ \\
\hline & 24 months & $2.8926 *$ & 2.667 & 3.119 & $<0.001$ \\
\hline \multirow{2}{*}{12 months } & 18 months & $\mathrm{I} .5773 *$ & 1.357 & 1.798 & $<0.001$ \\
\hline & 24 months & $\mathrm{I} .5524 *$ & 1.322 & 1.783 & $<0.001$ \\
\hline 18 months & 24 months & -0.0248 & -0.162 & 0.112 & $>0.05$ \\
\hline
\end{tabular}

Table 8 Mean, range and percentiles of af in the study group

\begin{tabular}{|c|c|c|c|c|c|c|c|c|c|}
\hline \multirow{2}{*}{$\begin{array}{l}\text { Age } \\
\text { AF Characteristics }\end{array}$} & \multirow{2}{*}{$\begin{array}{l}\text { Days } \\
7-F e b\end{array}$} & \multicolumn{3}{|l|}{ Weeks } & \multicolumn{5}{|c|}{ Months } \\
\hline & & 6 & 10 & 14 & 6 & 9 & 12 & 18 & 24 \\
\hline & $(n=3 \mid 3)$ & $(n=323)$ & $(n=325)$ & $(n=322)$ & -325 & -321 & $(n=321)$ & $(n=321)$ & $(n=324)$ \\
\hline \multirow[t]{2}{*}{ Mean size $( \pm S D)$} & 4.5 & 4.2 & 3.9 & 3.7 & 3.1 & 2.5 & 1.8 & 0.2 & 0 \\
\hline & \pm 1.7 & \pm 1.4 & \pm 1.5 & \pm 2.2 & \pm 1.0 & \pm 1.3 & \pm 1.3 & \pm 0.6 & \pm 0.7 \\
\hline Minimum size & 0 & 0 & 0 & 0 & 0 & 0 & 0 & 0 & 0 \\
\hline Maximum size & 7.9 & 6.6 & 6.9 & 3.6 & 6.6 & 5 & 4.7 & 3.3 & 3.8 \\
\hline 5th centile & 1.3 & 1.8 & 1.4 & I.5 & 0.5 & 0.9 & 0 & 0 & 0 \\
\hline I0th centile & 2 & 2.2 & 2 & 1.9 & 1.5 & I & 0 & 0 & 0 \\
\hline 25th centile & 3.5 & 3.5 & 2.9 & 2.8 & 2.1 & 1.3 & 0.5 & 0 & 0 \\
\hline 50th centile & 4.7 & 4.5 & 4.1 & 3.6 & 3.3 & 2.4 & 1.9 & 0 & 0 \\
\hline 75th centile & 5.8 & 5.2 & 5 & 4.3 & 4.1 & 3.6 & 2.8 & 0 & 0 \\
\hline 90th centile & 6.4 & 5.9 & 5.9 & 5.1 & 4.7 & 4.3 & 3.3 & 0.7 & I \\
\hline 95th centile & 6.7 & 6.2 & 6.2 & 5.9 & 5 & 4.7 & 4.7 & 1.2 & I.4 \\
\hline
\end{tabular}

ANOVA $=537.374, p<0.001$ for the variations of mean AF size with postnatal age

Table 9 Distribution of Anterior Fontanel size by Social class And age

\begin{tabular}{|c|c|c|c|c|c|c|c|c|c|}
\hline \multirow{2}{*}{ Social Class } & \multicolumn{9}{|c|}{ Mean \pm SD AF Size $(\mathrm{cm})$} \\
\hline & 2 - 7 days & 6 wks & 10 wks & I4 wks & $6 \mathrm{mo}$ & $9 \mathrm{mo}$ & $12 \mathrm{mo}$ & $18 \mathrm{mo}$ & $24 \mathrm{mo}$ \\
\hline $\mathrm{I}$ & $4.6(1.4)$ & $4.5(1.6)$ & $4.7(I .5)$ & $3.8(1.4)$ & $3.3(1.2)$ & $2.6(1.5$ & $0.9(0.8)$ & $0.1(0.4)$ & 0 \\
\hline II & $4.3(1.8)$ & 4.I(I.4) & $4.0(1.3)$ & $3.5(1.2)$ & $3.1(1.4)$ & $2.3(1.2$ & $1.5(I . I)$ & $0.2(0.6)$ & $0.2(0.5)$ \\
\hline III & $4.6(1.7)$ & $4.0(1.2)$ & $3.0(1.4)$ & $3.5(1.1)$ & $3.1(1.2)$ & $2.4(1.2$ & $2.4(1.5)$ & $0.2(0.7)$ & $0.6(1.3)$ \\
\hline IV & $4.4(1.8)$ & $4.1(1.2)$ & 4.I $(0.6)$ & $3.7(1.4)$ & $3.3(1.3)$ & $3.2(1.4$ & $0.3(0.8)$ & $0.3(0.4)$ & 0 \\
\hline V & $5.2(0.0)$ & $6.2(0.4)$ & $4.1(0.0)$ & $2.3(0.0)$ & $2.2(0.7)$ & 0 & $2.6(0.7)$ & 0 & 0 \\
\hline ANOVA & 0.839 & 4.073 & 4.68 & 0.937 & 21.674 & 1.015 & 1.075 & 0.722 & 1.13 \\
\hline $\mathrm{p}$ - value & 0.501 & 0.001 & 0 & 0.369 & 0.342 & 0.001 & 0 & $0.24 I$ & 0 \\
\hline
\end{tabular}

Citation: Okorie EMC, Opara PI,Alikor EAD, et al.Variations in anterior fontanel sizes in nigerian children in port harcourt metropolis.J Pediatr Neonatal Care. 2018;8(I):I-6. DOI: I0.15406/jpnc.2018.08.00306 
Table 10 Distribution of mean \pm SD of AF size by ethnic group(s) in newborns

\begin{tabular}{lll}
\hline Ethnic group(s) & No & Mean \pm (SD) AF size \\
\hline Ogoni & 36 & $6.4(\mathrm{I} .5)$ \\
Bini/Esan & 9 & $5.5(\mathrm{I} .4)$ \\
Anang/Ibibio/Oron lbo & 20 & $5.2(\mathrm{I} .6)$ \\
Ikwere / Etche & 50 & $5.1(\mathrm{I} .7)$ \\
Yoruba & 22 & $5.1(\mathrm{I} .5)$ \\
Urhobo/Itsekiri & 19 & $4.2(\mathrm{I} .3)$ \\
Igbo & 120 & $3.9(\mathrm{I} .7)$ \\
ljaw/Kalabari/Okirika & 22 & $3.7(\mathrm{I} .6)$ \\
Hausa/Fulani/Tiv/Lantan & 5 & $3.0(3.5)$ \\
Others & $3 \mathrm{I}$ & $4.9(\mathrm{I} .2)$ \\
Total & 313 &
\end{tabular}

Table I I Percentage closure of anterior fontanel by age

\begin{tabular}{|c|c|c|c|}
\hline Postnatal age & Males & Females & {$[(\mathrm{n}(\%) ;(95 \% \mathrm{Cl}$ of total)] } \\
\hline 2-7 days & $1532(2.2)$ & $1607(77.8)$ & $313[9(2.9) ; 0.66-2.64]$ \\
\hline 6 weeks & $1655(83.3)$ & I58 I(I6.7) & 323 [6 (1.9); $0.66-2.64]$ \\
\hline 10 weeks & $1670(0)$ & $1580(0)$ & $325[0(0 ;)]$ \\
\hline I4 weeks & $1544(100)$ & $1680(0)$ & $322[4(1.2) ; 0.19-1.60]$ \\
\hline 6 months & $1582(28.6)$ & $1675(7 \mid .4)$ & $325[7(2.2) ; 0.46-2.25]$ \\
\hline
\end{tabular}



Figure I A Scatter plot of variations of AF size by Age and Gender.

\section{Discussion}

The mean size of the anterior fontanel in this study decreased significantly with age. This trend has been documented by previous authors, ${ }^{4,71-24}$ among Caucasian, as well as black infants.

The mean AF size of $4.5 \pm 1.7 \mathrm{~cm}$ in newborns in this study is higher than that in previous reports from Nigeria..$^{9,14,21,24,25}$ However, there was marked variation between the sizes reported from previous studies. Thus, while Adeyemo et al. ${ }^{25}$ reported a mean AF size of 4.0 $\pm 1.0 \mathrm{~cm}$, Ogunye, et al., ${ }^{21}$ and Uzoukwu ${ }^{24}$ reported lower values of $3.3 \pm 2.0 \mathrm{~cm}$ and $2.78 \pm 0.82 \mathrm{~cm}$, respectively. One possible reason for the difference between the mean $\mathrm{AF}$ in the present study and previous studies could be the timing of the measurements, which was within 12 to 24 hours after birth in the series by Adeyemo et al. ${ }^{25}$ at 30 hours in that by Ogunye et al., ${ }^{21}$ and at 24-48 hours in that by Uzoukwu. ${ }^{24}$ Although the exact duration of the effects of molding on the AF is uncertain, it is likely that measurements taken after 48 hours and up to 7 days post-natal age as was done in the present study will reduce the effects of molding on AF size. The implication of this is that the higher values of AF sizes obtained in this study may be more valid than that from studies in which measurements were taken at less than 48 hours of age. It is thus possible that, if the timing of measurements in the previous Nigerian studies had been as in the present study, the results may have been similar.

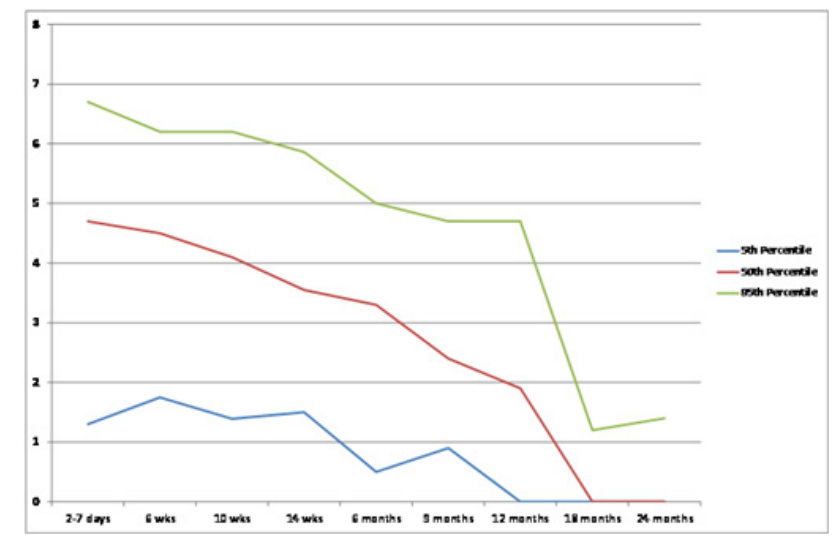

Figure 2 Variation in $5^{\text {th }}, 50^{\text {th }}$ and $95^{\text {th }}$ percentile of AF size with postnatal age. 


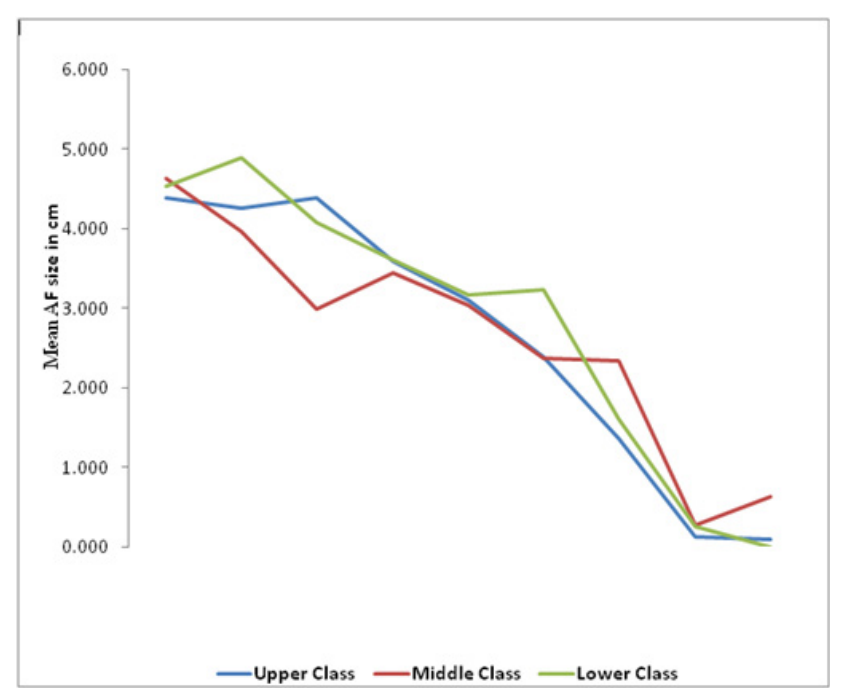

Figure 3 Variation of mean AF size by social class.

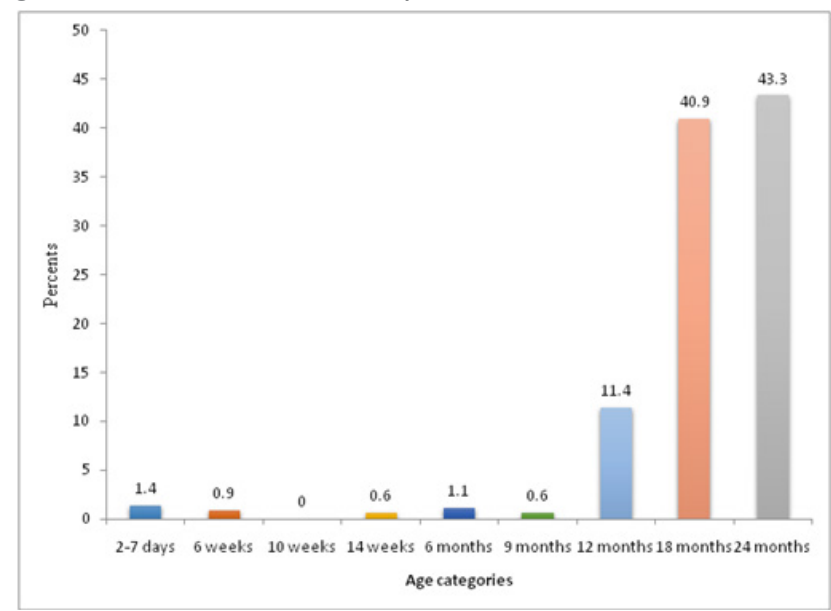

Figure 4 Variation in percentage closure of anterior fontanel with increasing postnatal age.

Another factor that may be responsible for the differences in mean AF size could be the method of measurement. In the method used by Popich and Smith, ${ }^{8}$ which was adopted by some of the other Researchers, ${ }^{9,14,25}$ it is not stated as to how the limits of the AF were delineated. The method of Faix, ${ }^{12}$ adopted by Uzoukwu, ${ }^{24}$ would appear to be less suitable for our newborns with luxuriant scalp hair, as it can predispose to falsely higher values. ${ }^{10,24}$ Accurate delineation of the limits of the AF dimension is paramount to getting a reliable measurement. ${ }^{10}$ Since the method of delineation of the AF by Faix ${ }^{12}$ and Uzoukwu, ${ }^{24}$ are fraught with some inherent errors, and the method by Popich and Smith, ${ }^{8}$ which was used by the other Researchers did not state how the AF was delineated, these may account for the lower values of $\mathrm{AF}$ sizes in their report compared to those in the present study.

The use of a pair of dividers aided by palpation as was employed in the present study would appear more appropriate as the limits of the AF can easily be delineated despite the luxuriant scalp hair in Nigerian newborns. On the other hand, the fact that the pointed tips of the pair of dividers were detached could affect the accuracy of AF size in this study. In addition, the subjects in this study were from diverse ethnic groups while the earlier Nigerian authors ${ }^{9,14,21,24}$ surveyed homogenous groups. The factors responsible for the variations in AF sizes between different ethnic groups demonstrated in this study are not clear and require further evaluation.
The mean size of AF in this study was also higher than the figures obtained from Caucasian ${ }^{8,12}$ and Oriental. The mean size of AF in this study was also higher than the figures obtained from Caucasian ${ }^{8,12}$ and Oriental populations. ${ }^{16,27}$ This is in accord with previous studies that have documented racial differences in the size of the anterior fontanel. ${ }^{12,14,16,21,27}$ However, it is possible that these differences may be related to the different methods employed in the measurement of the AF size. Although the extent to which the use of different methodologies influence the size of the AF remains to be determined, a generally larger AF size has been documented in black neonates compared to their white counterparts. ${ }^{8,12,27}$ This is thought to be due to delayed osseous maturation akin to that seen in small-for-date neonates and those with skeletal dysmorphogenesis. ${ }^{8,21}$

The relationship between AF size and gestational age as found in this study is similar to that documented previously, both locally $9,24,25,26$ and internationally. ${ }^{10,27,28}$ However, that no significant difference in the mean AF size was observed between the groups of preterm and term 6babies in the present study contrasts with the findings of other Nigerian authors..$^{14,24}$ The reason for this is not clear but may be related to the small sample size of the babies born at 28-32 weeks GA compared to those born at 33-36 weeks GA in the present study.

There was no statistically significant gender difference in the mean size of AF among the younger infants in the present study. This is in accord with previous studies, both locally ${ }^{14,24,26}$ and internationally. ${ }^{6,8,27}$ However at 24 months of age, the mean AF size was significantly lower in females. The reason for this is not clear but may be due to the female lead in skeletal maturation.

There was a significant relationship between anterior fontanel size and social class. This is similar to the finding of Acheson and Eirlys ${ }^{29}$ who noted a larger AF size in the lower social classes and an earlier closure in the higher social-economic strata. Further studies may be required to establish the relationship between nutritional status and AF size in Nigerian children.

The cosmopolitan nature of Port Harcourt City, the study area, is reflected in the diverse ethnic nationalities of the inhabitants. The relatively higher number of Igbo infants in this study may not be unrelated to the migrant nature of the Igbo who are found in every nook and cranny of the country and beyond. This is in addition to the fact that the Igbo speaking states of Imo and Abia are neighbouring states to Rivers State and are among the catchment area for UPTH. ${ }^{30}$

AF size varied widely among the different ethnic groups but among the newborns. This wide variation in AF size in line with the general wide wariation in anthropometric parameters in the human population. ${ }^{17,31}$ The largest AF size was observed among the Ogonis, while the Hausa/Fulan/Tiv/Lantang had the least AF size. The mean AF size in Igbo neonates in this study was similar to that reported by Uzoukwu ${ }^{24}$ among Igbo neonates in Enugu. This is perhaps a reflection of their common racial origin. Similarly, the mean AF size for the Yoruba newborns in this study was within the range reported by Omotade et al.14 This, therefore, suggests that genetics exacts a stronger influence on AF size compared to environmental factors. The significant difference in the mean AF sizes between the various ethnic groups studied is suggestive of inter-ethnic variations in the size of the AF. The factors responsible for these variations apart from genetic factors remain to be determined.

About $3 \%$ of the newborns in this study had a closed anterior fontanel. This is in contrast to the findings of Ogunye ${ }^{21}$ and Uzoukwu, ${ }^{24}$ who reported an open AF in all the newborns studied. Also this Researcher did not come across any published study that had reported closure of the AF fontanel in apparently healthy newborns. However, 
there was no obvious abnormality among the newborns in the present study and care had been taken to exclude all newborns with obvious neurological, skeletal, endocrine and chromosomal disorders. (The exclusion of these babies were based on clinical grounds as these infants have other features of disease condition. The baby with Down Syndrome will have certain dysmorphic features such as hypertelorism, low set ears, depressed nasal bridge, single transverse palmer crease and global hypotonia. The infant with a raised intracranial pressure may have a bulging AF, projectile vomiting, seizures etc. ${ }^{3}$ In addition to a widened $\mathrm{AF} /$ delayed closure of the anterior fontanel, the child with rickets may have genu varus/valgus deformity (resulting from poor mineralization of the long bones particularly the weight bearing bones of the lower limbs), macrocephaly, widening of the wrist bones and a rachitic rosary appearance of the ribs. One of the early signs of rickets is Craniotabes. ${ }^{16,18,27,32}$ This is a softening of the outer table of the skull bone which buckles under pressure producing a reaction similar to the indenting and popping out of a ping-pong ball) Moreover, definitive investigations such as Hormonal assays and karyotyping and imaging studies such as CT Scan and magnetic resonance imaging are could not be done in a resource constrained setting like ours). Therefore, the reason(s) for the finding of a closed AF in some of the newborns in the present study is/are not clear. Also, whether this is a normal variation in Nigerian children remains to be determined.

There was a steady increase in the proportion of subjects with a closed anterior fontanel with increasing post-natal age beyond 9 months of age. The percentage with a closed AF at 24 months $(88.9 \%)$ in the present study is similar to the $91 \%$ reported from Indian by Mattur et al33 In the series by Omotade et al., ${ }^{14} 11 \%$ of 6 months' infants and $53 \%$ of 12 months olds had a closed anterior fontanel. The percentage of infants with a closed anterior fontanel in the present study at 6 months of age is lower $(2.2 \%)$ while that at 12 months $(23.7 \%)$ is higher. Apart from the differences in methodology noted earlier, the larger sample size in the present study may also have played a role by increasing the chance of picking "abnormal" findings.

About $11 \%$ of the subjects in the present study still had an open $\mathrm{AF}$ at 24 months. This is higher than the $4 \%$ reported by Duc and Largo $^{26}$ from Zurich. It is possible that the relatively high prevalence of nutritional rickets in our environment could explain the high percentage of subjects with an open AF at 24 months in this study. ${ }^{32}$

Males had a significantly larger mean AF size at 24 months of age, whereas more females had a closed AF at same age. The difference in percentage closure between males and females was, however, not statistically significant. These findings contrast with those of Acheson and Eirly, who demonstrated earlier closure of the AF in European boys. However, Acheson and Eirlys study ${ }^{28}$ was conducted during a period of male preference with better nutrition in male children which could explain their findings. Further studies are required to confirm the findings in this study and to seek explanations for the male-female difference.

\section{Conclusion}

The size of the anterior fontanel in Nigerian children in the cosmopolitan city of Port Harcourt decreased progressively with post-natal age. There was a significant relationship between anterior fontanel size and social class and ethnic origin respectively. After 24 months AF sizes were significantly lower in females.

\section{Recommendation}

The percentile values for anterior fontanel size among the newborns and at various ages obtained in this study are recommended for use as reference standards in Nigerian infants in Port Harcourt.

\section{Limitation of the study}

A major limitation of this study was the time constraint posed by the necessity to complete this study within the time frame of the senior residency program. For this reason, a cross-sectional study was carried out, and therefore, percentage closure of the anterior fontanel was obtained rather than actual age at closure which would have required a longitudinal study.

Secondly, the method adapted for the estimation of the anterior fontanel size in this study may be a factor in the finding of a closed fontanel in 3\% of the newborns. Estimation of AF size by tansfontanel ultrasound may have given a more accurate result in terms of accurate delineation of the margins of the anterior fontanel.

\section{Conflicts of interest}

The authors declare that there are no conflicts of interest.

\section{Funding}

None.

\section{References}

1. Still BJ, Kliegman RM. The newborn infant. In: Behrman RE \& Kliegman RM (Eds.), Nelson Textbook of Pediatrics, (16th edn), Philadelphia. WB Saunders Co, USA. 2000. p.454-460.

2. Haslam RHA. Neurological evaluation. In: Behrman RE \& Kliegman RM (Eds.), Nelson Textbook of Pediatrics, (16th edn). Philadelphia. WB Saunders Co, USA. 2000. p.1793- 1866.

3. Kiesler J, Ricer R. The abnormal fontanel. Am Fam Phys. 2003;67(12):2547-2552

4. Soames R. Magnetic resonance imaging of the ligaments of the craniocervical region at 3Tesla magnetic resonance unit: Quantitative and qualitative assessment. In: Williams PL \& Bannister LH (Eds.), The Anatomical Basis of Medicine and Surgery, (38th edn). Churchill Livingstone, New York, USA. 1995. p.425-736.

5. BrandtI, Hodes DT, Reimnitz P. Die große Fontanelle als Fenster zum Gehirn - Normalwerte und Verschlußzeiten. The Anterior fontanel. 1986;198(4):330-336.

6. Finnegan M, Heisler R, Miller M. Webster's II New Riverside University Dictionary. Boston, Riverside Publishing Company, USA. 1984. p.1536.

7. Joseph J. The locomotor system. In: Hamilton WJ (Ed.), Textbook of Human Anatomy. (2nd edn) London, Macmillan Publishers, India. 1987. p.19-200.

8. Popich GA, Smith DW. Fontanels: range of normal size. J Pediatr 80(5): 749-752.

9. Adeyemo AA, Omotade OO (1999) Variation in fontanel size with gestational age. Early Hum Dev. 1972;54(3):207-214

10. Davies DP, Ansari BM, Cooke TJH. Anterior fontanel size in the neonate. Arch Dis Child. 1975; 50(1):81-83.

11. Mir NA, Weislaw R. Anterior fontanel size in Arab children. Standards for appropriately grown full term neonates. Ann Trop Paediatr. 1998;8(3):184-186.

12. Faix RG. Fontanel size in black and white term newborn infants. $J$ Pediatr. 1982;100(2):304-306.

13. Tan KL. Wide sutures and large fontanels in the newborn. Am J Dis Child. 1976;130(4):386-390

14. Omotade OO, Kayode CM, Adeyemo AA. Anterior fontanel size in Nigerian children. Ann Trop Paediatr. 1995;15(1):89-91.

15. Feingold M, Bossert WH. Normal values for selected physical parameters: An aid to syndrome delineation. Birth Defects. 1974;10(13):1-16. 
16. Laestadius BA, Aese MD, Smith DW. Normal inner canthil and outer orbital dimensions. J Pediatr. 1969;74(3):465-468.

17. Pryor HB. Objective measurement of inter-pupillary distance. Pediatrics. 1969;44(6):973-977.

18. Araoye MO. Determination of the Intervention Strategies for the Prevention of Fetal Macrosomia Dependent Cesarean Sections in Nigeria. In: Research Methodology with Statistics for Health and Social Sciences. (1st edn), Nathadox publishers, Ilorin, Nigeria. 2004. p.115-122.

19. Oyedeji GA. Determinants of Intention to Use Post Partum Family Planning among Women Attending Immunization Clinic of a Tertiary Hospital in Nigeria. Socioeconomic and cultural background of hospitalized children in Ilesa. Nig J Paediatr. 1985;12:11-17.

20. Deborah Ramsey (2nd edn), Statistics for Dummies.

21. Ogunye O, Ikeji MO, Adeodu O. Craniofacial dimensions in the African neonate. Niger J Paediatr. 1982;9:21-25.

22. Robinson DC, Hall R, Munro DS. Graves disease: an unusual complication-raised intracranial Pressure due to premature fussion of the skull sutures. Arch Dis Child. 1969;44(234):252-255.

23. Indira-Bai K, Subrahmanyam MVG, Subba-RaoKV. Fontanels: Range of normal size. Ind Paediatr. 1973;10(11):667-670.

24. Uzoukwu C. Assessment of anterior fontanelle sizes of Igbo newborns in Enugu Nigeria Dissertation submitted to West African College of Physicians. 2009.
25. Adeyemo AA, Olowu JA, Omotade OO. Fontanel size in term neonates in Ibadan, Nigeria. W Afr J Med. 1991;18(1):55-59.

26. Omotade OO. Facial measurements in children (towards syndrome delineation). I Med Genet. 1990;27(6):358-362.

27. Duc G, Largo RH. Anterior fontanel size and closure in term and preterm infants. Pediatrics. 1986; 78(5): 904-908.

28. Uzura M, Furuya Y, Mashi K, et al. Persistence of open fontanel in a 4-year-old girl. Child's Nerv Syst. 2005;21(1):83-85.

29. Acheson RM, Eirlys J. Some observations on the closure of anterior fontanelle. Arch Dis Child. 1954;29(145):196-198.

30. PH population. 2009.

31. Ibe BC, Nwosu Kc. Outer canthal, and inner canthal distance in Nigerian newborn babies, Paper presented at the 24th annual conference of the Paediatric Association of Nigeria, Nigeria. 1993.

32. AzubuikeJC. Endocrine and metabolic disorders. In: Azubuike JC \& Nkanginieme KEO (Eds.), Paediatrics and child health in a tropical region. Owerri, African Educational Services. 1999. p. 456-473.

33. Mattur S, Kunna R, Mathur GP, et al. Anterior Fontanelle size. Indian Pediatri. 1994;3:161-164. 